DOI $10.15593 / 2224-9354 / 2017.2 .3$

УДК 316.334 .55

\author{
В.Ю. Бочаров, Ю.В. Васькина
}

\title{
ОЦЕНКА СОСТОЯНИЯ СОЦИАЛЬНОЙ ИНФРАСТРУКТУРЫ СЕЛЬСКИХ ПОСЕЛЕНИЙ КАК ФАКТОР СОЦИАЛЬНОГО САМОЧУВСТВИЯ
}

\begin{abstract}
В статье рассматривается роль социальной инфраструктуры современного российского села в формировании социального самочувствия работников сельскохозяйственных предприятий и сельских предпринимателей (фермеров). На основе статистических данных и результатов, проведенных с участием авторов социологических исследований, характеризуется социально-экономическое положение коллективных и фермерских хозяйств по ряду параметров - численность хозяйств и ее динамика, обрабатываемые площади, объем производства продукции, проблемы сбыта, численность работников, их трудовой потенциал, приводится оценка работниками этих хозяйств различных элементов социальной инфраструктуры сел.

Результаты опросов показывают, что наименее развитыми элементами инфраструктуры являются спортивные объекты, досуговые центры, медицинские учреждения и работа транспорта. Авторы статьи делают вывод, что невозможность удовлетворить ряд потребностей по причине неразвитости инфраструктуры заставляет сельских жителей, особенно молодежь, переезжать в город.

Представлены данные о социальном самочувствии респондентов и о его обусловленности оценками состояния инфраструктуры сельских поселений. Наиболее важными для социального самочувствия фракторами могут быть названы состояние школьного и дошкольного образования, качество медицинского обслуживания, возможности физического развития, организация досуга и отдыха.

Анализируется мнение экспертов - работников областного министерства сельского хозяйства и руководителей районных администраций - о роли и перспективах программ социального развития села. По их словам, за прошедшее время с начала реализации национального проекта «Развитие АПК» и различных программ социального развития сельской местности, содержание волнующих сельских жителей проблем пока не изменилось.

Анализ сделан на основе данных мониторинговых исследований социально-трудовой сферы сельского хозяйства, проведенных в одном из регионов Поволжья в 2011-2013 годах.

Ключевые слова: мониторине социально-трудовой сфреры, фрермер, сельскохозяйственное предприятие, социальная инфраструктура, социальное самочувствие, индекс удовлетворенности.
\end{abstract}

Актуальность исследований уровня удовлетворенности социальной структурой сельских поселений. Одна из задач исследований социальнотрудовой сферы сельского хозяйства состоит в оценке уровня удовлетворенности респондентов состоянием социальной инфраструктуры сельских поселений, где они живут и работают.

Социальная инфраструктура представляет собой совокупность учреждений, объектов и связанных с ними видов деятельности, призванных удовлетворять социальные потребности людей, гарантировать необходимый уровень и качество

(c) Бочаров В.Ю., Васькина Ю.В., 2017

Бочаров Владислав Юрьевич - канд. социол. наук, доцент кафедры социологии и политологии ФГАОУ ВО «Самарский национальный исследовательский университет», ассоциированный научный сотрудник СИ РАН (г. Санкт-Петербург), e-mail: vlad-bocharov@ya.ru.

Васькина Юлия Владимировна - канд. социол. наук, доцент кафедры социологии и политологии ФГАОУ ВО «Самарский национальный исследовательский университет», ассоциированный научный сотрудник СИ РАН (г. Санкт-Петербург), e-mail: vaskina18.05@gmail.com. 
жизни, а также обеспечивать воспроизводство человеческих ресурсов [1, с. 331]. Наличие и разветвленность инфраструктуры обеспечивает удовлетворение материальных, социальных и духовных потребностей населения. Развитая социальная инфраструктура помогает не только удовлетворять названные потребности, но и экономить время на получение необходимых благ, высвобождая его для трудовой или рекреационной деятельности, а также обеспечивает стабилизацию населения, предотвращает его отток в другие населенные пункты.

Необходимость социального развития села является одним из приоритетов при возрождении отечественного агропромышленного комплекса. Этот факт признается на высшем государственном уровне. Так, еще в 2007 году Президент РФ В.В. Путин отмечал, насколько важно «сохранить сельский образ жизни, но в новом, современном его виде, развивая там инфраструктуру, дороги, транспорт, газовое обеспечение, в том числе за счет реализации на селе национальных проектов» (цит. по: [2, с. 69]). В то время шла реализация национального проекта «Развитие АПК» и выделялись серьезные средства на модернизацию социальной инфраструктуры сельских поселений. Данные проведенных нами в середине 2000-х мониторинговых исследований свидетельствовали о позитивной динамике в оценках состояния социальной инфраструктуры сельских поселений, связанной с реализацией национальных проектов [3]. В частности, данные мониторинга 2005 и 2007 годов $(N=750)$ свидетельствовали, что в целом работники коллективных хозяйств признавали удовлетворительной работу таких служб, как почта, телеграф, телефон, ветеринарная служба, транспортное сообщение с городом, районным центром. Их в достаточной степени устраивало качество школьного образования и социальное обслуживание пожилых и инвалидов. В то же время более критично респонденты оценивали уровень медицинского обслуживания и качество воды в своем сельском поселении [1, с. 142-143]. Очевидно, что позитивные сдвиги в модернизации социальной инфраструктуры российского села, связанные с реализацией национального проекта «Развитие АПК», произошли, однако это позволило лишь снизить остроту проблем, а не снять их. Об этом свидетельствуют многие научные публикации, которые обращают внимание на сохраняющуюся «отсталость» социальной инфраструктуры российского села. Можно привести в пример сборник социологических статей и эссе «Вдали от городов. Жизнь постсоветской деревни» [4].

В некоторых регионах осуществляются эмпирические социологические исследования, анализирующие взаимосвязь социальной инфраструктуры села и социального самочувствия жителей. Примером такого исследования является работа бурятских авторов Л.В. Бадмаевой и Г.В. Ганна [5].

Значимость развитой инфраструктуры села исследователи видят и в ее влиянии на трудовой потенциал, качество трудовых ресурсов [6].

Стоит сказать, что в докладах, прозвучавших на седьмых Санкт-Петербургских социологических чтениях «Социальные проблемы российского села 
и аграрных отношений», встречались достаточно критические отзывы о ситуации в российских селах. Например, один из докладов носил название «Российская деревня - зона гуманитарной катастрофы: пути преодоления» [7].

О сохраняющихся проблемах в состоянии социальной инфраструктуры сельских поселений свидетельствуют и данные наших мониторинговых исследований 2012-2013 годов, проведенных на сельскохозяйственных предприятиях и в фермерских хозяйствах муниципальных районов одного из регионов Поволжья.

Эмпирическая база мониторинговых исследований социально-трудовой сферы сельского хозяйства. Мониторинговые социологические исследования, осуществляемые НИИ социальных технологий Самарского университета (бывший Самарский государственный университет - СамГУ), основываются на массовом опросе респондентов (анкетный опрос и полуформализованные интервью). Заказчиком исследований является региональное правительство. Научное руководство проектом осуществляет доцент Самарского университета Н.В. Авдошина, являющаяся директором НИИ социальных технологий. Общая методология мониторинговых исследований представлена в статьях Н.В. Авдошиной [8] и Б.Г. Тукумцева [9]. История возникновения мониторинговых исследований описана их инициатором, который по сей день является их активным участником и научным консультантом, - Б.Г. Тукумцевым [10].

Методология и программа мониторинговых исследований сельскохозяйственных предприятий (коллективных хозяйств) и фермерских хозяйств, а также полученные ранее результаты подробно представлены в коллективной монографии «Социально-трудовая сфера сельского хозяйства Самарской области: состояние, тенденции, перспективы» [1], а также в статьях В.Ю. Бочарова $[11,12]$ и А.Ф. Боковенко [13].

В настоящей статье приведены данные опросов работников сельскохозяйственных предприятий (коллективных хозяйств), проведенных в 2011 и 2013 годах $(N=700)$, а также данные мониторингового исследования состояния социально-трудовой сферы крестьянских (фермерских) хозяйств, выполненного в 2012 году $(N=200)$ (для сравнения приводятся данные аналогичного исследования 2008 года, $N=200)$. Помимо проведения анкетного опроса, в ходе каждого исследования были проведены интервью с руководителями сельскохозяйственных предприятий и крестьянских фермерских хозяйств, специалистами муниципальных управлений сельского хозяйства и регионального министерства сельского хозяйства и продовольствия.

Социально-экономическая ситуация в агропромышленном комплексе региона. Согласно данным территориальной службы государственной статистики на 01.01.2013, в регионе Поволжья, где в режиме мониторинга проводились наши исследования, работало 1034 сельскохозяйственных организации, в которых было занято более 1,9 млн работников. Эти же данные свиде-

PNRPU Sociology and Economics Bulletin. 2017. No. 2 35 
тельствовали о том, что по сравнению с предыдущим годом здесь наблюдалось сокращение численности населения трудоспособного возраста сельских поселений региона и сокращение количества коллективных хозяйств, не относящихся к субъектам малого предпринимательства (табл. 1).

Таблица 1

Число сельскохозяйственных организаций одного из российских регионов Поволжья (данные Территориального органа Федеральной службы государственной статистики)

\begin{tabular}{|c|c|c|c|c|c|}
\hline \multirow{2}{*}{$\begin{array}{c}\text { Численность населения } \\
\text { трудоспособного возраста } \\
\text { на конец года, чел. }\end{array}$} & \multicolumn{3}{|c|}{ Сельскохозяйственные организации, ед. } \\
\cline { 2 - 5 } & $\begin{array}{c}\text { не относящиеся к субъектам } \\
\text { малого предпринимательства }\end{array}$ & $\begin{array}{c}\text { субъекты малого } \\
\text { предпринимательства }\end{array}$ \\
\hline 2011 & 2012 & 2011 & 2012 & 2011 & 2012 \\
\hline 1953853 & 1926313 & 211 & 203 & 625 & 831 \\
\hline
\end{tabular}

Соответственно в 2011, 2012 годах наблюдалась тенденция сокращения среднесписочной численности работников и в сельском хозяйстве. На 01.01.2013 среднесписочная численность работников (без внешних совместителей) в сельском хозяйстве составила 22700 чел., или 1,18 \% от численности населения трудоспособного возраста Поволжского региона (на 01.01.2012 - 24600 чел.). На момент проведения исследования во втором полугодии 2013 года среднесписочная численность работников (без внешних совместителей) в сельском хозяйстве региона сократилась до 20100 чел.

Похожая тенденция наблюдается и среди крестьянских (фермерских) хозяйств региона, численность которых неуклонно сокращается, начиная с 2001 года (табл. 2).

Таблица 2

Общее количество крестьянских (фермерских) хозяйств

и индивидуальных предпринимателей сельских районов одного из российских регионов Поволжья

(данные Территориального органа Федеральной службы государственной статистики, на конец года)

\begin{tabular}{|c|c||c|c|}
\hline Год & Количество хозяйств & Год & Количество хозяйств \\
\hline 2001 & 3517 & 2008 & 2730 \\
\hline 2002 & 3274 & 2009 & 2676 \\
\hline 2003 & 3201 & 2010 & 2773 \\
\hline 2004 & 3043 & 2011 & 2603 \\
\hline 2005 & 3050 & 2012 & 2451 \\
\hline 2006 & 2882 & 2013 & 2353 \\
\hline 2007 & 2857 & 2014 & 2323 \\
\hline
\end{tabular}


В то же время, по сравнению с данными предыдущих мониторинговых исследований, проведенных в 2008 году, в целом ситуация в социальнотрудовой сфере сельскохозяйственных предприятий и крестьянских (фермерских) хозяйств улучшилась. Во многом это было связано с реализацией ряда федеральных и региональных целевых программ, направленных на поддержку аграрного производства. Так, например, за последние годы в целом выросла большая часть валовых показателей животноводства и растениеводства региона, увеличилась производительность и урожайность, произошло расширение посевных площадей, введены в действие новые животноводческие комплексы. Незначительными темпами, но обновлялись основные фонды сельскохозяйственных предприятий и модернизировались сельскохозяйственная техника и инвентарь. Отметим, что статистические данные также свидетельствуют о заметном росте продукции, произведенной крестьянскими (фермерскими) хозяйствами, увеличении площади обрабатываемых фермерами земель (в том числе пашни) и численности имеющегося у них крупного рогатого скота (в том числе коров, свиней, овец и коз), и это несмотря на сокращение численности самих хозяйств.

В результате таких позитивных изменений примерно 70 \% опрошенных работников коллективных хозяйств региона в 2013 году указывали, что их коллективное хозяйство работает нормально, а почти $90 \%$ респондентов выражали уверенность, что дела у их коллективного хозяйства в ближайшем будущем будут только улучшаться. При этом почти 3/4 опрошенных работников сельхозпредприятий в 2013 году были удовлетворены своей работой, что свидетельствовало о высоком уровне стабильности персонала и больших надеждах, связанных с улучшением дел на своем сельхозпредприятии. Важно отметить, что в 2013 году доля работников сельхозпредприятий, удовлетворенных условиями своего труда, увеличилась и достигла более 70 \%. При этом в 1,6 раза, по сравнению с результатами опроса в 2011 году, сократилась доля работников, которым приходилось трудиться с нарушением техники безопасности.

Позитивные тенденции можно отметить и по данным опроса сельских предпринимателей (фермеров). Почти 40 \% опрошенных в 2012 году фермеров сообщили об увеличении своего земельного надела за последние 3 года. В целом, по сравнению с 2008 годом, существенно уменьшилась доля фермерских хозяйств с земельными площадями от 100 до 500 га (с 53,5 до 37,1 \%). При этом выросла доля фермеров, в распоряжении которых находится более 500 га земли. В 2012 году появились хозяйства, в распоряжении которых находится более 5000 га земли. Неудивительно, что доля фермеров, использующих в своих хозяйствах наемную рабочую силу, существенно выросла по отношению ко всем предыдущим мониторинговым замерам и составила в 2012 году более 4/5 опрошенных фермеров. В то же время необходимо иметь в виду, что рост объемов достигается исключительно за счет роста производительности фермерских хо- 
зяйств, расширения посевных площадей, увеличения поголовья скота, ведь численность крестьянских (фермерских) хозяйств в регионе не растет.

Состояние социально-трудовой сферы сельхозпредприятий и крестьянских (фермерских) хозяйств. Позитивные изменения, происходившие в социально-экономической сфере сельхозпредприятий и крестьянских (фермерских) хозяйств региона Поволжья в 2011-2013 годах, безусловно, не являются показателем всеобщего благополучия и успешного решения копившихся годами проблем. Многие показатели состояния социально-трудовой сферы по-прежнему нуждаются в корректировке и приложении усилий со стороны государства, органов местного самоуправления и руководителей сельскохозяйственных предприятий. Наиболее острыми проблемами, выявленными в ходе исследований 2012, 2013 годов, были следующие:

1. Всеми экспертами исследований и руководителями коллективных хозяйств наиболее острой признавалась проблема старения кадрового состава сельхозпредприятий. Несмотря на меры по привлечению молодежи в сельскую местность, решить эту проблему в полной мере пока не удается. Поэтому уже сегодня одни сельхозпредприятия начинают испытывать серьезный «кадровый голод», а другие могут столкнуться с этой ситуацией в течение ближайших 5 лет. При этом дефицит кадров осложняется миграционной убылью населения в большинстве обследованных муниципальных районов, т.е. процесс оттока трудовых ресурсов из сельской местности продолжается. Такая ситуация свидетельствует также и о том, что меры по созданию в селах предприятий перерабатывающей промышленности пока что не приносят желаемого результата, причем, в первую очередь, из-за недостаточности их масштаба.

2. Во многом проблема дефицита кадров и нежелания молодежи работать в сельской местности связана с проблемой невысоких заработков в коллективных хозяйствах. Темпы роста номинальной зарплаты в сельском хозяйстве по-прежнему недостаточны, а ее соотношение с величиной прожиточного минимума (ПМ) в 2013 году практически не изменилось по сравнению с 2011 годом. Кроме того, более 9/10 опрошенных работников коллективных хозяйств в 2013 году получали заработную плату в размере ниже 2 ПМ, а более половины работников коллективных хозяйств были не удовлетворены оплатой своего труда. Видя такие заработки, сельская молодежь, как и прежде, стремится уехать в город.

3. О создании условий для нормальной работы фермерских хозяйств в 2012 году сообщил только каждый пятый опрошенный фермер. При этом, по сравнению с 2008 годом, практически не уменьшилась доля фермеров, отмечающих, что в нашем регионе почти нет условий для переработки продукции (более $1 / 3$ опрошенных) и условий для сбыта продукции (почти 30 \% опрошенных).

4. Эффективный механизм защиты фермеров от рисков с помощью предоставления им выгодных страховых услуг не создан. Уровень доверия к работающим на рынке страховых услуг компаниям очень низок, а доля ферме- 
ров, пользующихся различными услугами страхования, в 2012 году была незначительна. Менее $1 / 5$ опрошенных пользуются страхованием своей техники и здоровья, менее 1/10 опрошенных страхуют свою жизнь и имущество, и лишь единицы (1,3\%) пользуются страхованием посевов. Также очень малая часть опрошенных в целом по массиву $(3,8$ \%) считают систему страхования посевов, техники и скота эффективной для предотвращения убытков.

5. По результатам проведенного в 2012 году исследования нельзя однозначно указать на высокий трудовой потенциал фермеров. С одной стороны, фермеры характеризуются высоким уровнем образования, хорошей оценкой состояния своего здоровья, что является залогом высокого трудового потенциала. С другой стороны, опрошенные фермеры не стремятся обновлять свои знания, а их здоровье испытывает негативное влияние в процессе трудовой деятельности, при этом возможностей полноценного отдыха у большинства фермеров нет (около $70 \%$ респондентов не отдыхали в течение прошлого года, при этом $3 / 4$ из них - по причине занятости в своем хозяйстве), т.е. у большинства опрошенных фермеров отмечена хроническая утомляемость, обусловленная интенсивной работой в хозяйстве. Это ослабляет их трудовой потенциал, мешает восстановлению физических сил. Трудовой потенциал ослабляется и достаточно большим средним возрастом фермеров ( $2 / 3$ из них старше 46 лет), отсутствием среди них молодежи. В этой связи следует отметить, что трудовой потенциал фермерства систематически не поддерживается и не восстанавливается, и в недалеком будущем его снижение может существенно сказаться на результатах трудовой деятельности.

6. Анализ доходов фермеров показывает, что далеко не все фермеры в 2012 году имели возможность получать прибыль от своих хозяйств. Каждый третий указывал, что он не может рассчитывать на прибыль. Положительным моментом можно считать рост доли фермеров, чьи хозяйства за последние 2 года улучшают свое положение, однако даже это улучшение не вызывает удовлетворенности у респондентов. Фермеров, не удовлетворенных доходами своих хозяйств, на $10 \%$ больше, чем удовлетворенных. В таких условиях у них возникает желание отказаться от ведения хозяйства и освоить другой вид деятельности.

7. Материальное положение фермеров и их семей нельзя назвать высоким. Об этом можно судить по следующим данным, полученным в ходе опроса в 2012 году: до 70 \% опрошенных фермеров оценивают уровень материального благосостояния своей семьи как средний; примерно от 40 до 50 \% семей фермеров обследованных муниципальных районов могут быть отнесены к группе низкообеспеченных; только около 30 \% фермеров рассчитывают на увеличение дохода своей семьи в течение следующего года, тогда как более 40 \% уверены, что ситуация с уровнем их семейного дохода не изменится. Все это говорит о том, что до настоящего времени еще не созданы материальные стимулы, которые бы побуждали людей, работающих в других сферах занятости, заняться совершенно новым для себя делом - фермерством. Только очевидная выгода 
этой деятельности может изменить обстановку с развитием фермерства. И не только выгода, но и поддержание определенного статуса: четкая программа поддержки в создании базы - от техники до жилья, всесторонняя поддержка и уважение со стороны властных структур, федеральных чиновников, органов правопорядка. Ведь фермер живет и работает в зоне риска, он взял на себя ответственность за успех урожая.

8. Несмотря на то, что жилищные условия большинства фермеров можно считать удовлетворительными (более $90 \%$ опрошенных имеют собственное жилье - квартиру или дом; средняя обеспеченность площадью жилых помещений выше федерального стандарта; 3/4 опрошенных удовлетворены своими жилищными условиями), следует отметить недостаточный уровень благоустроенности жилья определенной части респондентов: они не имеют благоустроенной квартиры, телефона, выхода в Интернет. При этом необходимо понимать, что люди, не обеспеченные комфортным жильем достаточной площади, выражают намерение уехать из своего населенного пункта.

Оценка фермерами состояния социальной инфраструктуры сельских поселений. В ходе опроса 2012 года фермеры давали оценку состояния различных элементов социальной инфраструктуры села, в котором они проживают (табл. 3).

Таблица 3

Распределение ответов на вопрос: «В какой степени Вас устраивает или не устраивает состояние перечисленных ниже сторон

Вашей жизни в селе?» (доли ответов в процентах)

\begin{tabular}{|l|c|c|c|c|}
\hline \multicolumn{1}{|c|}{ Стороны жизни в селе } & $\begin{array}{c}\text { Вполне } \\
\text { или отчасти } \\
\text { устраивает }\end{array}$ & $\begin{array}{c}\text { Совершенно } \\
\text { или скорее } \\
\text { не устраивает }\end{array}$ & $\begin{array}{c}\text { Трудно } \\
\text { сказать }\end{array}$ & Итого \\
\hline $\begin{array}{l}\text { Возможность получения профессио- } \\
\text { нального образования членами семьи }\end{array}$ & 67,9 & 19,3 & 12,8 & 100,0 \\
\hline Возможности повышения квалификации & 53,1 & 29,7 & 17,2 & 100,0 \\
\hline Качество школьного образования & 64,1 & 22,2 & 13,7 & 100,0 \\
\hline Качество медицинского обслуживания & 32,1 & 58,0 & 9,9 & 100,0 \\
\hline $\begin{array}{l}\text { Возможность укрепления здоровья } \\
\text { и физического развития }\end{array}$ & 40,0 & 46,3 & 13,7 & 100,0 \\
\hline Организация досуга и отдыха & 29,7 & 53,1 & 17,2 & 100,0 \\
\hline $\begin{array}{l}\text { Работа предприятий бытового обслужи- } \\
\text { вания (бани, химчистки, парикмахер- } \\
\text { ской и т.п.) }\end{array}$ & 34,6 & 43,2 & 22,2 & 100,0 \\
\hline $\begin{array}{l}\text { Работа пассажирского транспорта } \\
\text { (вязь с райцентром, городом) }\end{array}$ & 58,0 & 26,0 & 16,0 & 100,0 \\
\hline $\begin{array}{l}\text { Банковское обслуживание. } \\
\text { Доступ к потребительским кредитам }\end{array}$ & 65,4 & 16,1 & 18,5 & 100,0 \\
\hline Доступ к ипотеке & 50,6 & 32,1 & 17,3 & 100,0 \\
\hline
\end{tabular}


Окончание табл. 3

\begin{tabular}{|l|c|c|c|c|}
\hline \multicolumn{1}{|c|}{ Стороны жизни в селе } & $\begin{array}{c}\text { Вполне } \\
\text { или отчасти } \\
\text { устраивает }\end{array}$ & $\begin{array}{c}\text { Совершенно } \\
\text { или скорее } \\
\text { не устраивает }\end{array}$ & $\begin{array}{c}\text { Трудно } \\
\text { сказать }\end{array}$ & Итого \\
\hline Состояние дорог & 25,9 & 60,5 & 13,6 & 100,0 \\
\hline Уровень развития телефонной связи & 66,7 & 19,7 & 13,6 & 100,0 \\
\hline Работа почты & 71,2 & 15,0 & 13,8 & 100,0 \\
\hline $\begin{array}{l}\text { Работа социальных служб (помощь по- } \\
\text { жилым, инвалидам, многодетным и т.д.) }\end{array}$ & 58,7 & 22,6 & 18,7 & 100,0 \\
\hline
\end{tabular}

Разные элементы социальной инфраструктуры вызывают неодинаковую степень удовлетворенности респондентов. Так, наиболее высоко респонденты оценивают работу почты, возможность получения профессионального образования, уровень развития телефонной связи, качество школьного образования и доступ к банковским услугам (кредитам). От $2 / 3$ до $3 / 4$ опрошенных удовлетворены указанными сторонами жизни в селе. Напротив, очень низко оценены состояние дорог, качество медицинского обслуживания и организация досуга и отдыха.

Уровень удовлетворенности различными аспектами социальной инфраструктуры отражен в значениях индексов удовлетворенности, представленных в ранжированном виде по результатам исследования 2012 года в сравнении с данными исследования 2008 года в табл. 4.

Таблица 4

Индексы удовлетворенности различными сторонами жизни в селе (ранжировано по мере уменьшения значения индекса по данным исследования 2012 г.)

\begin{tabular}{|l|c|c|}
\hline \multicolumn{1}{|c|}{ Стороны жизни в селе } & \multicolumn{2}{c|}{ Значение индексов } \\
\cline { 2 - 3 } & 2012 г. & 2008 г. \\
\hline Работа почты & 0,36 & 0,48 \\
\hline $\begin{array}{l}\text { Возможность получения профессионального } \\
\text { образования членами семьи }\end{array}$ & 0,33 & 0,13 \\
\hline Уровень развития телефонной связи & 0,32 & 0,34 \\
\hline $\begin{array}{l}\text { Банковское обслуживание. Доступ к потребительским } \\
\text { кредитам }\end{array}$ & 0,29 & 0,13 \\
\hline Качество школьного образования & 0,27 & 0,03 \\
\hline $\begin{array}{l}\text { Работа социальных служб (помощь пожилым, } \\
\text { инвалидам, многодетным и т.д.) }\end{array}$ & 0,24 & 0,43 \\
\hline Возможности повышения квалификации & 0,16 & Не обслед. \\
\hline $\begin{array}{l}\text { Работа пассажирского транспорта } \\
\text { (связь с райцентром, городом) }\end{array}$ & 0,14 & $-0,18$ \\
\hline Доступ к ипотеке & 0,05 & $-0,19$ \\
\hline $\begin{array}{l}\text { Возможность укрепления здоровья } \\
\text { и физического развития }\end{array}$ & $-0,09$ & $-0,19$ \\
\hline
\end{tabular}


Окончание табл. 4

\begin{tabular}{|l|c|c|}
\hline \multicolumn{1}{|c|}{ Стороны жизни в селе } & \multicolumn{2}{c|}{ Значение индексов } \\
\cline { 2 - 3 } & 2012 г. & 2008 г. \\
\hline $\begin{array}{l}\text { Работа предприятий бытового обслуживания } \\
\text { (бани, химчистки, парикмахерской и т.п.) }\end{array}$ & $-0,11$ & $-0,55$ \\
\hline Организация досуга и отдыха & $-0,17$ & $-0,29$ \\
\hline Качество медицинского обслуживания & $-0,18$ & $-0,37$ \\
\hline Состояние дорог & $-0,32$ & Не обслед. \\
\hline
\end{tabular}

Примечание. Индексы удовлетворенности имеют значение от $(+1)$ до (-1). В качестве алгоритма расчета использована формула, приведенная в книге «Человек и его работа в СССР и после» и употребляемая там для определения величины коэффициента удовлетворенности респондентов своей работой [14, с. 76].

Со времени исследования, проведенного в 2008 году, значения индексов удовлетворенности менялись как в сторону увеличения, так и снижения. Позитивная динамика уровня удовлетворенности имеет место при оценке возможности получения профессионального образования, банковского обслуживания (доступ к кредитам), качества школьного образования, работы пассажирского транспорта, доступа к ипотеке. Есть и ряд других элементов социальной инфраструктуры, в отношении которых снизилась степень неудовлетворенности, но значение индексов по-прежнему отрицательное: работа предприятий бытового обслуживания, организация досуга и отдыха, качество медицинского обслуживания.

В то же время некоторые составляющие социальной инфраструктуры села на большинстве территорий получили чрезвычайно низкие оценки. К ним относятся: состояние дорог, качество медицинского обслуживания и организация досуга и отдыха. При этом опрошенные фермеры в большинстве своем дают осторожные оценки возможных будущих изменений условий жизни в их селе.

Только треть опрошенных (38,1\%) полагают, что условия жизни будут улучшаться, почти столько же $(37,1 \%)$ думают, что изменений к лучшему не произойдет; затрудняются ответить 24,7 \%. Эти данные свидетельствуют о недооценке руководителями муниципальных районных управлений значения жизненных условий в селах, находящихся в зоне их ответственности, при решении такого стратегически важного вопроса, как развитие фермерства.

Итак, по мнению сельских предпринимателей - фермеров - социальная инфраструктура села развита неравномерно как в структурном, так и в территориальном плане. Тем не менее хорошо функционируют, по оценкам фермеров, учреждения профессионального и школьного образования, социальные службы и почта. Неразвиты структурные элементы, относящиеся к организации досуга, неудовлетворительное состояние медицин- 
ской помощи и дорог. Все это в итоге является одним из факторов непрерывной тенденции сокращения количества сельских предпринимателей (об этом говорилось выше, см. табл. 2).

Удовлетворенность работников сельскохозяйственных предприятий работой учреждений социальной инфраструктуры. Похожие оценки были получены в исследовании 2013 года, в рамках которого опрашивались наемные работники сельскохозяйственных предприятий. В ходе исследования респондентов просили оценить, насколько их устраивает работа различных объектов и оказание некоторых видов услуг в рамках социальной инфраструктуры (табл. 5).

Таблица 5

Удовлетворенность работников сельхозпредприятий работой учреждений социальной инфраструктуры (доли ответов в процентах)

\begin{tabular}{|c|c|c|c|c|c|c|}
\hline $\begin{array}{c}\text { Оцениваемые параметры } \\
\text { инфраструктуры }\end{array}$ & 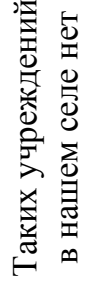 & 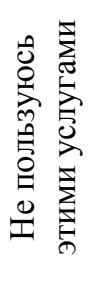 & 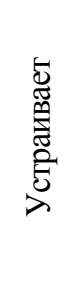 & 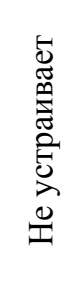 & 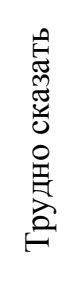 & $\stackrel{0}{\stackrel{0}{0}}$ \\
\hline Качество дошкольного образования & 6,1 & 52,1 & 28,7 & 8,9 & 4,3 & 100,0 \\
\hline Качество школьного образования & 2,9 & 45,2 & 33,2 & 12,4 & 6,4 & 100,0 \\
\hline Медицинское обслуживание & 3,1 & 3,1 & 44,5 & 38,4 & 11,0 & 100,0 \\
\hline $\begin{array}{l}\text { Возможности укрепления физического } \\
\text { здоровья и развития }\end{array}$ & 32,3 & 17,2 & 22,5 & 26,0 & 2,1 & 100,0 \\
\hline Организация досуга и отдыха & 16,5 & 18,9 & 25,6 & 32,3 & 6,7 & 100,0 \\
\hline Работа пассажирского транспорта & 2,1 & 16,2 & 49,1 & 26,8 & 5,8 & 100,0 \\
\hline Доступ к ипотеке, жилищному кредиту & 7,7 & 51,9 & 12,6 & 22,1 & 5,6 & 100,0 \\
\hline Доступ к потребительским кредитам & 6,8 & 35,9 & 35,9 & 17,1 & 4,3 & 100,0 \\
\hline Качество стационарной телефонной связи & 1,4 & 38,2 & 42,1 & 16,1 & 2,1 & 100,0 \\
\hline Качество мобильной телефонной связи & 0,7 & 1,4 & 76,0 & 19,1 & 2,8 & 100,0 \\
\hline Работа почты, телеграфа & 0,7 & 2,8 & 86,4 & 7,0 & 3,1 & 100,0 \\
\hline $\begin{array}{l}\text { Социальное обслуживание пожилых } \\
\text { и инвалидов }\end{array}$ & 5,0 & 43,6 & 39,0 & 7,4 & 5,0 & 100,0 \\
\hline
\end{tabular}


Наиболее высокие оценки заслужили у работников коллективных хозяйств услуги: сотовой связи и почты (более трех четвертей опрошенных довольны их работой). Недовольство работников связано с такими видами услуг, как медицинские, спортивные, рекреационно-досуговые и транспортные. Что касается отсутствующих объектов инфраструктуры, то треть опрошенных сообщили, что они не имеют возможности укреплять свое физическое здоровье, следовательно, в селах не хватает спортивных сооружений, а для молодежи это весьма актуально.

Неудивительно, что в таких условиях среди работников сельскохозяйственных предприятий желающих обеспечить занятость самостоятельно - открыть свое дело или стать фермерами - немного (табл. 6).

Таблица 6

Распределение ответов на вопрос: «Хотели бы Вы лично открыть свое дело или заняться фермерством?»

(доли ответов в процентах)

\begin{tabular}{|c|c|c|c|c|}
\hline Год мониторинга & Да & Нет & Затруднились ответить & Итого \\
\hline 2013 & 12,1 & 76,4 & 11,5 & 100,0 \\
\hline 2011 & 13,2 & 69,8 & 17,0 & 100,0 \\
\hline
\end{tabular}

Три четверти опрошенных не желали бы становиться предпринимателями. Доля таких ответов выросла по сравнению с 2011 годом на 6,6 \%.

Низкие оценки состояния многих элементов социальной инфраструктуры, несомненно, вносят свой вклад в формирование социального самочувствия жителей села - как работников коллективных хозяйств, так и фермеров.

Зависимость социального самочувствия от уровня удовлетворенности состоянием социальной инфраструктуры сельских поселений. Социальное самочувствие - это восприятие жизненных обстоятельств и оценка перспектив их изменения. Социальное самочувствие реагирует на совокупность разнообразных факторов: уровень и качество жизни, ситуацию в политической и экономической сферах общества, состояние семейных отношений, условия труда и многие другие аспекты жизни человека [15, с. 307]. Опыт проведенных мониторинговых исследований позволяет сказать, что низкий уровень социального самочувствия создает неблагоприятные психологические условия для самоотдачи работника на его рабочем месте, для гарантии качества его труда и в целом включенности в трудовую деятельность [16].

В мониторинговых исследованиях 2012, 2013 годов социальное самочувствие изучалось с помощью таких показателей, как удовлетворенность жизненными обстоятельствами, выяснение причин неудовлетворенности и мнения респондентов о перспективах изменения жизни семьи в ближайшем будущем.

Наиболее информативным показателем социального самочувствия является степень удовлетворенности жизнью (табл. 7). 
Удовлетворенность респондентов тем, как складывается жизнь (доли ответов в процентах)

\begin{tabular}{|l|c|c|c|c|c|}
\hline $\begin{array}{c}\text { Категория } \\
\text { респондентов } \\
\text { (год опроса) }\end{array}$ & $\begin{array}{c}\text { Жизнью } \\
\text { вполне и скореее } \\
\text { удовлетворены }\end{array}$ & $\begin{array}{c}\text { Затруднились } \\
\text { ответить }\end{array}$ & $\begin{array}{c}\text { Жизнью } \\
\text { совершенно } \\
\text { или скорее } \\
\text { не удовлетворены }\end{array}$ & Итого & $\begin{array}{c}\text { Индекс } \\
\text { удовлет- } \\
\text { воренности }\end{array}$ \\
\hline $\begin{array}{l}\text { Работники } \\
\text { коллективных } \\
\text { хозяйств (2013 г.) }\end{array}$ & 59,2 & 15,7 & 25,1 & 100,0 & 0,26 \\
\hline Фермеры (2012 г.) & 64,2 & 22,2 & 13,6 & 100,0 & 0,35 \\
\hline
\end{tabular}

Менее двух третьих опрошенных в целом удовлетворены жизнью. Это люди, которых можно рассматривать как адаптированных к жизни в сельской местности. Отметим, что показатель неудовлетворенности жизнью среди работников сельскохозяйственных предприятий почти в 2 раза выше, чем среди фермеров.

Работники сельскохозяйственных предприятий, не удовлетворенные жизнью, сообщали в ходе опроса 2013 года о причинах неудовлетворенности:

Материальные причины

Состояние здоровья (и невозможность его

поправить при плохом медобслуживании)

Отсутствие жилья

Ситуация в стране и регионе (нестабильность, коррупция, некомпетентное управление,

в т. ч. переход на московское время)

Нет возможности отдыхать

Проблемы личной жизни

$$
55,2 \%
$$

$11,9 \%$

$9,0 \%$

$7,5 \%$

$7,5 \%$

$4,5 \%$

Более половины респондентов, объяснявших, почему они не удовлетворены жизнью, назвали материальные причины - низкие доходы, бытовую необустроенность, невозможность удовлетворять потребности членов семьи. Названные причины очевидно коррелируют с низкими оценками ряда параметров социальной инфраструктуры сельских поселений.

Доля удовлетворенных жизнью среди тех, кто по-разному оценивает состояние сочиальной инфраструктуры:

Качество дошкольного образования:

среди тех, кого качество устраивает

$61,6 \%$

среди тех, кого качество не устраивает

$42,3 \%$

Качество школьного образования:

среди тех, кого качество устраивает

$63,0 \%$

среди тех, кого качество не устраивает

$32,9 \%$ 
Медицинское обслуживание:

среди тех, кого устраивает медобслуживание

$65,2 \%$

среди тех, кого не устраивает медобслуживание

$47,2 \%$

Возможность укрепления здоровья и физического развития:

среди тех, кого устраивают возможности

$72,3 \%$

среди тех, кого не устраивают возможности

$45,9 \%$

Организация досуга и отдыха:

среди тех, кого устраивает организация

$69,6 \%$

среди тех, кого не устраивает организация

$50,8 \%$

Приведенные данные показывают, что главный показатель социального самочувствия напрямую зависит от оценки респондентами состояния отдельных элементов социальной инфраструктуры. Показана взаимосвязь удовлетворенности жизнью и оценки тех элементов инфраструктуры, которые получили наиболее отрицательные отзывы среди опрошенных. Однако остальные элементы инфраструктуры также имеют значение для формирования социального самочувствия.

Существенно в меньшей степени, как показал статистический анализ, удовлетворенность жизнью зависит от состояния здоровья, жилищных условий, ситуации в стране и других проблем.

Говоря об оценках жизненных перспектив, стоит отметить, что менее половины опрошенных в 2012 году фермеров ощущали уверенность в завтрашнем дне (доли ответов в процентах):

вполне и отчасти уверены 46,3

совершенно или скорее не уверены. 15,0

затруднились ответить

итого 100,0

Доля неуверенных составила лишь $15 \%$. Но к ним необходимо добавить почти $40 \%$ тех, кто ушел от ответа. И тогда станет очевидным, что более половины фермеров, опрошенных исследователями, не имеют четкой уверенности в делах и жизни на перспективу.

Работникам коллективных хозяйств задавался вопрос о том, каких изменений своей жизни они ожидают в ближайшем будущем (доли ответов в процентах):

значительно лучше


Довольно большая доля опрошенных не смогла дать определенного ответа на вопрос, как изменится в будущем положение их семей. Примерно четверть опрошенных считают, что жизнь семей улучшится; еще четверть что не изменится; каждый двадцатый респондент ожидает ухудшений.

Таким образом, около $40 \%$ респондентов (как работников коллективных хозяйств, так и фермеров) затрудняются оценить будущие изменения, т.е. живут в состоянии неопределенности.

Мнение экспертов мониторинговых исследований 2012, 2013 годов о необходимости модернизации социальной инфраструктуры сельских поселений. Проблема состояния социальной инфраструктуры и благоустройства многих сел вызывает обеспокоенность как со стороны работников сельскохозяйственных предприятий и фермеров, так и со стороны экспертов проведенных исследований. Вот слова руководителя одного из коллективных хозяйств, обследованных в 2013 году: «Хоромо, что у нас асфальтированная дорога есть, а заедешь дальше от нее - вообще никакой дороги нет в ту сторону. Ну, мы ровняем там, но как дожди пойдут, там надо в болотных сапогах ходить, вот проблема какая». Недостаточная благоустроенность села вызывает тревогу руководителей, главным образом, в связи с проблемой оттока молодежи в город. По их мнению, современные молодые люди подвержены влиянию средств массовой информации, формирующих «глянцевый» образ жизни в городе, транслирующих стандарты качества жизни, к которым нужно стремиться. Это заставляет молодежь искать «красивую жизнь», которой в своем селе они не видят.

Тему низкого уровня благоустройства села можно продолжить и тем фактом, что в некоторые села только в 2012 году провели газ, и не все дома успели подключить к газоснабжению. Дороги же, по оценкам местных жителей, пришли к ним «в последнюю очередь».

Руководители многих сельскохозяйственных предприятий сообщали исследователям, что раньше, еще в советское время, благоустройство и социальная инфраструктура сел поддерживались за счет коллективных хозяйств, которые несли ответственность за их состояние. В настоящее же время коллективные хозяйства не имеют средств для этих целей. Строительство дорог недоступно для них в связи с большими затратами на эти цели. Исследователи столкнулись с фактом, когда одно из обследованных в 2013 году коллективных хозяйств не могло позволить себе заасфальтировать часть дороги, ведущей на ферму, и доставка кормов и вывоз молока представляли большую проблему.

Актуальной проблемой является культурное развитие села. Действующие в районных центрах и селах учреждения культуры не справляются с функцией организации полноценного досуга - из районов, расположенных близко к городам, молодежь едет в него, однако эти поездки многим не по карману.

Проблемы проведения досуга обостряются еще и в связи с большой занятостью работников в хозяйствах в период сезонных работ, когда график не позволяет не только отдохнуть, но и справиться с бытовыми делами.

PNRPU Sociology and Economics Bulletin. 2017. No. 2 
В связи с недостаточной развитостью социальной инфраструктуры сел эксперты исследований 2012, 2013 годов высказывали мнение о необходимости дальнейшей разработки и реализации программ, направленных на поддержку села. Подчеркивалась необходимость комплексной согласованной программы, которая бы предусматривала различные аспекты жизни села, чтобы не повторялась ситуация, когда за каждый элемент социальной инфраструктуры отвечает отдельное ведомство, не рассматривая проблемы в комплексе.

Bbводы. Проведенные мониторинговые исследования 2011-2013 годов, в ходе которых выяснялась оценка социальной инфраструктуры села работниками коллективных хозяйств и фермерами, позволили сделать ряд выводов:

1. Наиболее высоко респонденты оценивают работу почты, уровень развития телефонной связи, качество школьного образования и доступ к банковским услугам (кредитам). Напротив, очень низко оценены состояние дорог, развитость общественного транспорта, качество медицинского обслуживания, организация досуга и отдыха, возможности заниматься физкультурой и спортом.

2. В исследованиях 2011-2013 годов были выявлены практически неизменные проблемы состояния сельской социальной инфраструктуры - отсутствие спортивных объектов, плохое медицинское обслуживание, неорганизованный досуг и неудовлетворительная работа транспорта. За прошедшее время, несмотря на реализацию программ социального развития села, список волнующих сельских жителей проблем не изменился.

3. Анализ полученных в исследованиях данных показал, что оценка состояния социальной инфраструктуры является одним из факторов формирования социального самочувствия жителей села. Чем меньше удовлетворены респонденты состоянием различных элементов социальной инфраструктуры, тем ниже их удовлетворенность жизнью.

4. Важно обратить внимание, что доля неудовлетворенных жизнью среди фермеров в 2 раза ниже, чем среди работников коллективных хозяйств. Это различие можно объяснить тем, что фермеры являются субъектами предпринимательства, т.е. людьми, принимающими ответственность за себя и своих работников, умеющими противостоять негативным факторам. В этой связи фермеры демонстрируют большую степень уверенности в своих силах и, как следствие, более высокую удовлетворенность жизнью. В то же время в последние несколько лет отмечается сокращение числа фермерских хозяйств, т.е. становится меньше людей, готовых принимать условия ведения сельскохозяйственного бизнеса.

Во многом на решение отмеченных проблем нацелена российская государственная программа «Развитие сельского хозяйства и регулирование рынков сельскохозяйственного производства, сырья и продовольствия на 2013-2020 годы» [17]. Однако очевидно, что экономический кризис 2015, 2016 годов существенно скорректировал возможные государственные инвестиции в социальную инфраструктуру сельских поселений. В то же время недостаточность инвестиций в социальную инфраструктуру и отсутствие средств у муниципа- 
литетов на серьезное обновление существующих объектов и строительство новых являются серьезным препятствием для внедрения социальных инноваций в российских сельских территориях. Необходимо помнить, что современные жители села ориентируются не только на возможные доходы, но и на определенное качество жизни, перспективы улучшения которого в сельской местности они не почувствовали.

В целом неразвитая социальная инфраструктура одновременно является одной из причин сокращения количества крестьянских фермерских хозяйств, а также причиной нежелания молодежи заниматься предпринимательством на селе. И ситуация практически не меняется. Так, в исследовании 2013 года были выявлены те же актуальные проблемы состояния социальной инфраструктуры, что и в 2011 году: отсутствие спортивных объектов, плохое медицинское обслуживание, неорганизованный досуг, плохое водоснабжение, отсутствие благоустройства и неудовлетворительная работа транспорта. За прошедшее время, несмотря на реализацию национального проекта «Развитие АПК» и различных программ социального развития сельской местности, содержание волнующих сельских жителей проблем не изменилось. Между тем необходимо иметь в виду, что именно комплексное развитие села может предотвратить отток молодежи в города и обеспечить сельхозпредприятия необходимыми кадрами. Важно понимать, что современные работники сельхозпредприятий ориентируются не только на возможные доходы, но и на определенное качество жизни, улучшение которого в сельской местности они еще не почувствовали. Следует отметить, что в интересах закрепления людей в сельской местности и особенно молодежи, а также предоставления работы механизаторам в межсезонье необходимо стимулировать открытие производственных предприятий малого бизнеса в сельской местности, развивать сферу сервиса. Важно понимать, что эффект от действия государственных программ по поддержке села наступает не сразу, поэтому уже в настоящее время необходимо искать резервы развития трудового потенциала сельхозпредприятий, принимать меры для налаживания диалога с работниками, искать новые подходы к мотивации работников высокопроизводительного труда (которая, по данным исследования 2013 года, находится на низком уровне [18, с. 7-11]), усиливать внимание к использованию высокопроизводительной и автоматизированной техники и агротехнологий, высвобождающих людей.

\section{Список литературы}

1. Социально-трудовая сфера сельского хозяйства Самарской области: состояние, тенденции, перспективы: моногр. / под ред. А.Ф. Боковенко, В.Ю. Бочарова, Е.Ф. Молевича. - Самара: Самарский университет, 2010. - 528 с.

2. Родионова Г.А. Особенности национального проектирования сельской жизни // Социологические исследования. - 2007. - № 7. - С. 66-72. 
3. Бочаров В.Ю., Лазарев А.В. Удовлетворенность уровнем развития социальной инфраструктуры и реализацией национальных проектов на селе в Самарской области // Экономика сельскохозяйственных и перерабатывающих предприятий. -2009 . - № 7. - С. 66-68.

4. Вдали от городов. Жизнь постсоветской деревни / под ред. Е. Богдановой, О. Бредниковой. - СПб.: Алетейя, 2013. - 232 с.

5. Бадмаева Л.В., Ганн Г.В. Социальное самочувствие населения как индикатор развития социальной инфраструктуры села Бурятии // Ойкумена. Регионоведческие исследования. - 2011. - № 3. - С. 90-98.

6. Данилова И.В., Лавров В.Н., Илюхина С.В. Социальная инфраструктура села как фактор управления качеством трудовых ресурсов // Вестник Южно-Уральского государственного университета. Экономика и менеджмент. - 2010. - № 26 (202). - С. 113-117.

7. Божков О.Б. Социальные проблемы российского села и аграрных отношений // Телескоп: журнал социологических и маркетинговых исследований. - 2015. - № 3 (111). - С. 50-52.

8. Авдошина Н.В. Социально-трудовая сфера как объект социологического анализа // Проблемы труда, трудовых отношений и качества жизни: сб. науч. материалов Всерос. науч.-практ. конф., Самара, 11-12 октября 2007 г. Самара: Универс групп, 2007. - С. 144-156.

9. Тукумцев Б.Г. Самарский мониторинг социально-трудовой сферы // Социологические исследования. - 2001. - № 7. - С. 41-50.

10. Тукумцев Б.Г. Из истории Самарского мониторинга социально-трудовой сферы // Юбилейный сборник научных трудов преподавателей, аспирантов и магистрантов социологического факультета Самарского государственного университета. - Самара: Самарский университет, 2014. - С. 415-423.

11. Бочаров В.Ю. Мониторинг социально-трудовой сферы сельского хозяйства Самарской области // Экономика сельскохозяйственных и перерабатывающих предприятий. - 2008. - № 11. - С. 72-74.

12. Бочаров В.Ю. Мониторинг социально-трудовой сферы сельского хозяйства: история, методология и результаты исследований 2011-2013 гг. // Юбилейный сборник научных трудов преподавателей, аспирантов и магистрантов социологического факультета Самарского государственного университета. - Самара: Самарский университет, 2014. - С. 433-446.

13. Бочаров В.Ю., Боковенко А.Ф. Социально-экономическая ситуация в фермерских хозяйствах Самарской области // Экономика сельскохозяйственных и перерабатывающих предприятий. - 2009. - № 10. - С. 62-65.

14. Здравомыслов А.Г., Ядов В.А. Человек и его работа в СССР и после: учеб. пособие для вузов. - 2-е изд., испр. и доп. - М.: Аспект Пресс, 2003. -485 с.

15. Васькина Ю.В. Социальное самочувствие работников // Социология труда. Теоретико-прикладной толковый словарь / под ред. В.А. Ядова. СПб.: Наука, 2006. - С. 307. 
16. Бочаров В.Ю., Васькина Ю.В. Комплексная методика измерения социального самочувствия в массовых социологических опросах // Studium-XII: Модернизация социальных систем в современном российском обществе: потенциал и практика повседневности / под общ. ред. О.А. Кармадонова, В.А. Решетникова. - Иркутск: Изд-во Иркут. гос. ун-та, 2011. - С. 25-29.

17. Государственная программа «Развитие сельского хозяйства и регулирования рынков сельскохозяйственного производства, сырья и продовольствия на 2013-2020 годы» [Электронный ресурс]: утв. постановлением Правительства РФ № 717 от 14.07.2012 г., с изм. от 19.12.2014 г. - URL: http://base.garant.ru/70210644/ (дата обращения: 02.07.2016).

18. Бочаров В.Ю. Уровень мотивации работников сельскохозяйственных предприятий к труду // Экономика и социология. - 2015. - № 3 (27). - С. 7-11.

\section{References}

1. Sotsial'no-trudovaia sfera sel'skogo khoziaistva Samarskoi oblasti: sostoianie, tendentsii, perspektivy [Social and labor sphere of agriculture in Samara Oblast: state, trends and prospects]. Ed. by A.F. Bokovenko, V.Iu. Bocharov, E.F. Molevich. Samara, Samarskii universitet, 2010, 528 p.

2. Rodionova G.A. Osobennosti natsional'nogo proektirovaniia sel'skoi zhizni [Features of the national design of rural life]. Sotsiologicheskie issledovaniia, 2007, no. 7, pp. 66-72.

3. Bocharov V.Iu., Lazarev A.V. Udovletvorennost' urovnem razvitiia sotsial'noi infrastruktury i realizatsiei natsional'nykh proektov na sele v Samarskoi oblasti [Satisfaction with the level of social infrastructure development and national projects implementation in rural areas of Samara Oblast]. Ekonomika sel'skokhoziaistvennykh $i$ pererabatyvaiushchikh predpriiatii, 2009, no. 7, pp. 66-68.

4. Vdali ot gorodov. Zhizn' postsovetskoi derevni [Far from the city. The life of the post-Soviet village]. Ed. by E. Bogdanova, O. Brednikova. Saint-Petersburg, Aleteiia Publ., 2013, 232 p.

5. Badmaeva L.V., Gann G.V. Sotsial'noe samochuvstvie naseleniia kak indikator razvitiia sotsial'noi infrastruktury sela Buriatii [The social well-being as an indicator of social infrastructure development of Buryatia villages]. Oikumena. Regionovedcheskie issledovaniia, 2011, no. 3, pp. 90-98.

6. Danilova I.V., Lavrov V.N., Iliukhina S.V. Sotsial'naia infrastruktura sela kak faktor upravleniia kachestvom trudovykh resursov [Social infrastructure of the village as a factor of labor resources quality management]. Vestnik Iuzhno-Ural'skogo gosudarstvennogo universiteta. Ekonomika i menedzhment, 2010, no. 26, vol. 202, pp. 113-117.

7. Bozhkov O.B. Sotsial'nye problemy rossiiskogo sela i agrarnykh otnoshenii [Social problems of the Russian village and agrarian relations]. Teleskop: zhurnal sotsiologicheskikh i marketingovykh issledovanii, 2015, no. 3, vol. 111, pp. 50-51. 
8. Avdoshina N.V. Sotsial'no-trudovaia sfera kak ob"ekt sotsiologicheskogo analiza [Social labor sphere as the object of sociological analysis]. Problemy truda, trudovykh otnoshenii i kachestva zhizni: sb. nauch. materialov Vseros. nauch.prakt. konf., Samara, 11-12 October 2007 [Proc. All-Russ. Sci. Pract. Conf. "Problems of labor, workplace relations and quality of life"]. Samara, Univers grupp Publ., 2007, pp. 144-156.

9. Tukumtsev B.G. Samarskii monitoring sotsial'no-trudovoi sfery [Samara monitoring of social and labor spheres] Sotsiologicheskie issledovaniia, 2001, no. 7, pp. 41-50.

10. Tukumtsev B.G. Iz istorii Samarskogo monitoringa sotsial'no-trudovoi sfery [From the history of the social and labor sphere monitoring in Samara]. Samara, Samarskii universitet Publ., 2014, pp. 415-423.

11. Bocharov V.Iu. Monitoring sotsial'no-trudovoi sfery sel'skogo khoziaistva Samarskoi oblasti [Agricultural social and labor sphere monitoring in Samara Oblast]. Ekonomika sel'skokhoziaistvennykh $i$ pererabatyvaiushchikh predpriiatii, 2008, no. 11, pp. 72-74.

12. Bocharov V.Iu. Monitoring sotsial'no-trudovoi sfery sel'skogo khoziaistva: istoriia, metodologiia i rezul'taty issledovanii 2011-2013 gg. [Agricultural social and labor sphere monitoring: history, methodology and research findings in 2011-2013]. Samara, Samarskii universitet Publ., 2014, pp. 433-446.

13. Bocharov V.Iu., Bokovenko A.F. Sotsial'no-ekonomicheskaia situatsiia v fermerskikh khoziaistvakh Samarskoi oblasti [Socio-economic situation in the farms of Samara Oblast]. Ekonomika sel'skokhoziaistvennykh $i$ pererabatyvaiushchikh predpriiatii, 2009, no. 10, pp. 62-65.

14. Zdravomyslov A.G., Iadov V.A. Chelovek i ego rabota v SSSR i posle [Person and the work in and after the USSR]. 2nd ed. revised and corrected. Moscow, Aspekt Press Publ., 2003, 485 p.

15. Vas'kina Iu.V. Sotsial'noe samochuvstvie rabotnikov [Social well-being of workers]. Sotsiologiia truda. Teoretiko-prikladnoi tolkovyi slovar'. Ed. by V.A. Iadov. Saint-Petersburg, Nauka Publ., 2006, p. 307.

16. Bocharov V.Iu., Vas'kina Iu.V. Kompleksnaia metodika izmereniia sotsial'nogo samochuvstviia $\mathrm{v}$ massovykh sotsiologicheskikh oprosakh [Comprehensive methodology for measuring social well-being in mass sociological surveys]. Studium-XII: Modernizatsiia sotsial'nykh sistem v sovremennom rossiiskom obshchestve: potentsial i praktika povsednevnosti. Ed. by O.A. Karmadonov, V.A. Reshetnikov. Irkutsk, Irkut. Gos. Un-t Publ., 2011, pp. 25-29.

17. Gosudarstvennaia programma "Razvitiia sel'skogo khoziaistva i regulirovaniia rynkov sel'skokhoziaistvennogo proizvodstva, syr'ia i prodovol'stviia na 2013-2020 gody”. Utverzhdena postanovleniem Pravitel'stva RF № 717 ot 14.07.2012 g., s izm. ot 19.12.2014 g. [State program of "Agricultural development and regulation of agricultural production markets, raw materials and food for 
2013-2020". Approved by the Resolution of the Government of the Russian Federation no. 717 of 14 Jul. 2012, as amended on 19 Dec. 2014]. Available at: http://base.garant.ru/70210644/ (accessed 02 July 2016).

18. Bocharov V.Iu. Uroven' motivatsii rabotnikov sel'skokhoziaistvennykh predpriiatii $\mathrm{k}$ trudu [The level of agricultural workers motivation to labor]. Ekonomika i sotsiologiia, 2015, no. 3, vol. 27, pp. 7-11.

Оригинальность статьи - $94 \%$

Получено 23.11.2016

V.Yu. Bocharov, Yu.V. Vaskina

\title{
ESTIMATION OF SOCIAL INFRASTRUCTURE CONDITION IN RURAL SETTLEMENTS AS A FACTOR OF SOCIAL WELL-BEING
}

\begin{abstract}
The article deals with defining the role of modern Russian village infrastructure in farmers' wellbeing formation. Based on the statistics and findings of the study, the authors characterize socioeconomic conditions of collective and private farms according to several parameters. They include the farms quantity dynamics, cultivated areas, products output, sales problems as well as the number of employees and their labor potential, with the evaluation of various elements of rural settlement' social infrastructure by the workers.

The results of the survey demonstrate that sports facilities, leisure centers, health-care facilities, and transport appear the least developed social infrastructure elements. The authors draw a conclusion that the infrastructure underdevelopment, as well as the inability to satisfy the needs of the population, results in the younger generation movement from rural to urban areas. The paper presents the statistics on the respondents' social welfare and its correlation with the evaluation of the rural settlements infrastructure. Among the most important factors of social well-being the authors name the quality of school and pre-school education, healthcare services as well as the opportunities for sportsmanship and leisure.

The study analyzes the experts' views, including those of the members of regional department of agriculture and local managing directors, upon the role and prospects of rural area development programs. According to their viewpoints, since the implementation of the national project of agro-industrial development as well as various programs of rural development that followed, the essence of the problems that worried the village residents remained unchanged.

The analysis is based on findings of the surveillance study of social and labor sphere, carried out in one of the Povolzhye regions between 2011 and 2013.

Keywords: social and labor sphere monitoring, farmer, agricultural enterprise, social infrastructure, social well-being, satisfaction index.

Vladislav Yu. Bocharov - Candidate of Sociological Sciences, Associate Professor, Dept. of Sociology and Political Science, Samara University, e-mail: vlad-bocharov@ya.ru.

Yuliya V. Vaskina - Candidate of Sociological Sciences, Associate Professor, Dept. of Sociology and Political Science, Samara University, e-mail: vaskina18.05@gmail.com.
\end{abstract}

